УДК $332.14(571.65)$

\title{
РЕЙТИНГ СОЦИАЛЬНО-ЭКОНОМИЧЕСКОГО ПОЛОЖЕНИЯ МУНИЦИПАЛЬНЫХ ОБРАЗОВАНИЙ МАГАДАНСКОЙ ОБЛАСТИ (2007-2018 гг.)
}

\author{
Шарыпова О. А., Гальцева Н. В., Фавстрицкая О. С. \\ ФГБУН Северо-Восточный комплексный научно-исследовательский институт \\ им. Н. А. Шило ДВО РАН, г. Магадан \\ E-mail: olga@north-east.ru,galtseva@neisri.ru,favstritskaya@neisri.ru
}

\begin{abstract}
Выполнен сравнительный анализ социально-экономического положения Магаданской области в 2007 и 2018 г. по основным показателям. Проведена рейтинговая оценка муниципальных образований (городских округов) Магаданской области по социально-экономическому положению на основе трех групп показателей: производственной, финансовой, социальной. Определены районы - лидеры и аутсайдеры. Выполнен качественный анализ результатов обобщенного рейтинга социально-экономического положения районов Магаданской области в 2007 и 2018 г.
\end{abstract}

Ключевые слова: муниципальные образования, районы, Магаданская область, социально-экономическое положение, рейтинговая оценка.

DOI: 10.34078/1814-0998-2019-4-95-108

\section{ВВЕДЕНИЕ}

Магаданская область относится к регионам Крайнего Севера России. По ряду социальноэкономических показателей она входит в пятерку лучших регионов России и на первый взгляд характеризуется социальными преимуществами: высокими доходами населения, низким уровнем безработицы, высокой обеспеченностью жильем. Однако непрекращающийся с 90-х гг. $\mathrm{XX}$ в. отток населения из региона, а также внутрирегиональная миграция из периферийных районов в областной центр приводят к сжатию сети расселения и создают угрозу опустошения территории Крайнего Северо-Востока России, что требует выявления существующих проблем и модернизации пространственного развития региона. Модернизация, учитывающая природногеографические особенности, ресурсообеспеченность, инфраструктурную обустроенность, экономические и демографические возможности, уровень развития транспортных сетей, необходима в целях совершенствования пространственной (территориальной) организации в регионе.

Районы Крайнего Севера имеют свои особенности в управлении и социально-экономическом развитии (Ушаков, 2016). Магаданская область по 2019

(C) Шарыпова О. А., Гальцева Н. В., Фавстрицкая О. С., площади занимает 9-е место* в Российской Федерации, но при этом характеризуется высокой пространственной рассредоточенностью, низкой плотностью населения, невысокой хозяйственной освоенностью со слабым развитием транспортной и энергетической инфраструктуры. Данные обстоятельства обусловливают необходимость оценки социально-экономического положения и определения направлений модернизации экономики региона в разрезе административнотерриториального деления путем выявления районов-лидеров и неблагополучных муниципальных образований.

\section{ДАННЫЕ И МЕТОДЫ ИССЛЕДОВАНИЯ}

Цель исследования заключалась в определении проблем и направлений модернизации социально-экономического положения Магаданской области в районном (пространственном) разрезе посредством ранжирования муниципальных образований региона по основным общедоступным статистическим индикаторам.

Объект исследования - районы (городские округа) Магаданской области. Предмет исследования - уровень социально-экономического развития каждого района (городского округа).

*Площадь территории Магаданской области составляет 462.5 тыс. км². 
Одним из распространенных методов сопоставления уровней социально-экономического положения субъектов, районов, городов является рейтинг, который позволяет определить сильные и слабые звенья единого целого и впоследствии руководствоваться полученными результатами в разработке и реализации различных программ по развитию той или иной территории.

Существуют различные методики проведения рейтинговых оценок: методика Института социально-экономических и энергетических проблем Севера Коми НЦ РАН, Министерства экономического развития и торговли РФ, Госкомстата РФ, Вологодского научного центра РАН, Института экономики Карельского НЦ PAН, Института экономики и организации промышленного производства и др.

Для определения рейтинга социально-экономического положения районов Магаданской области использован методический подход Госкомстата РФ, основанный на ранжировании по данным оперативной статистики. Рейтинг проводили в три этапа (рис. 1).

Базой для сравнения произошедших изменений социально-экономических показателей в районном разрезе выбран 2007 г. - дата проведения аналогичной оценки (Шарыпова и др., 2009; Шарыпова, 2011).

Эмпирической базой исследования явились данные Министерства экономического развития, инвестиционной политики и инноваций Магаданской области; Госкомстата России и его территориального Управления федеральной службы государственной статистики по Хабаровскому краю, Магаданской области, Еврейской автономной области и Чукотскому автономному округу; информационные ресурсы городских округов Магаданской области, а также аналитические и практические разработки авторов.
Результаты исследования и их обсуждение. Для начала оценим, как изменился уровень социально-экономического положения Магаданской области в целом с 2007 по 2018 г. по основным показателям, по которым принято ранжировать регионы в рамках официальных публикаций Федеральной службы государственной статистики (табл. 1).

По численности населения на 01.01.2008 г. регион занимал 81-е место, на 01.01.2018 г. - 83-е. На начало 2019 г. численность населения составила 141.2 тыс. чел., что на 22.8 тыс. чел. (14\%) меньше, чем в 2007 г. Снижением численности населения обусловлено «движение вверх» показателей, рассчитываемых на душу населения или на 100, 1000, 10 000, 100000 чел. Это: ВРП на душу населения, инвестиции в основной капитал на душу населения, оборот розничной торговли на душу населения, число персональных компьютеров на 100 работников, число собственных легковых автомобилей на 1000 чел. населения.

В связи с этим настораживает тот факт, что имеется тенденция снижения важных для региона следующих показателей: поступление налогов, сборов и иных обязательных платежей в бюджетную систему РФ на душу населения; ввод в действие жилых домов на 1000 чел. населения; общая площадь жилых помещений, приходящаяся в среднем на одного жителя; число зарегистрированных преступлений на 100000 чел. населения.

Несмотря на то что по показателю «Инвестиции в основной капитал» регион переместился с 77-го на 55-е место, наблюдается снижение позиций по показателю «Полная учетная стоимость основных фондов в экономике региона», что свидетельствует об увеличении износа основных производственных фондов.

\begin{tabular}{|c|} 
1. Рейтинг по состоянию на определенный год \\
по 3 группам показателей на основе статистических данных за анализируемый год: \\
1) производственная сфера, \\
2) финансовая сфера, \\
3) социальная сфера
\end{tabular}

\section{2. Рейтинг по динамике развития}

Темпы роста показателей социально-экономического развития районов

\section{3. Интегральный рейтинг}

Обобщение социально-экономического положения районов в базовом году и в динамике развития

Puc. 1. Схема алгоритма проведения рейтинга социально-экономического положения районов Магаданской области

Fig. 1. Outline of the algorithm for rating the socio-economic situation in Magadan Oblast districts 
Таблица 1. Место, занимаемое Магаданской областью в РФ по основным социально-экономическим показателям в 2007 г. (на 01.01.2008 г.) и 2018 г. (на 01.01.2019 г.)

Table 1. Magadan Oblast position in the Russian Federation by the key socio-economic indicators in 2007 (on 01.01.2008) and 2018 (on 01.01.2019)

\begin{tabular}{|c|c|c|c|c|c|}
\hline & Показатель & $2018^{*}$ & $2007 * *$ & \begin{tabular}{|c|} 
Изменения \\
позиции \\
$2018 / 2007$ \\
\end{tabular} & $\begin{array}{l}\text { Характер динамики: } \\
\text { + положительная, } \\
\text { - отрицательная } \\
\end{array}$ \\
\hline \multicolumn{2}{|c|}{ Площадь территории } & 9 -e & $11-\mathrm{e}$ & +2 & + \\
\hline \multicolumn{2}{|c|}{ Численность населения на 1 января 2019 г. } & $83-\mathrm{e}$ & $81-\mathrm{e}$ & -2 & - \\
\hline \multicolumn{2}{|c|}{$\begin{array}{l}\text { Поступление налогов, сборов и иных обязательных пла- } \\
\text { тежей в бюджетную систему РФ на душу населения }\end{array}$} & $27-e$ & $22-\mathrm{e}$ & -5 & - \\
\hline \multicolumn{2}{|c|}{ ВРП на душу населения в 2016 / в 2006} & $7-\mathrm{e}$ & $11-\mathrm{e}$ & +4 & + \\
\hline \multicolumn{2}{|c|}{ Инвестиции в основной капитал } & $55-\mathrm{e}^{* * *}$ & $77-e$ & +22 & + \\
\hline \multicolumn{2}{|c|}{ Инвестиции в основной капитал на душу населения } & $6-e$ & $22-\mathrm{e}$ & +16 & + \\
\hline \multicolumn{2}{|c|}{$\begin{array}{l}\text { Основные фонды в экономике (по полной учетной } \\
\text { стоимости; на конец года) }\end{array}$} & $75-\mathrm{e}$ & $72-\mathrm{e}$ & -3 & - \\
\hline \multirow{4}{*}{$\begin{array}{l}\text { Объем отгру- } \\
\text { женных товаров } \\
\text { собственного } \\
\text { производства, вы- } \\
\text { полненных работ } \\
\text { и услуг собствен- } \\
\text { ными силами по } \\
\text { видам экономиче- } \\
\text { ской деятельности }\end{array}$} & Добыча полезных ископаемых & \multirow{4}{*}{$\begin{array}{l}\text { 69-e } \\
\text { (в 2017-71-e, } \\
\text { в 2007-70-е) }\end{array}$} & $27-\mathrm{e}$ & +9 & + \\
\hline & Обрабатывающие производства & & $74-\mathrm{e}$ & -5 & - \\
\hline & $\begin{array}{l}\text { Обеспечение электрической } \\
\text { энергией, газом и паром; конди- } \\
\text { ционирование воздуха }\end{array}$ & & \multirow[b]{2}{*}{$68-e$} & +2 & + \\
\hline & $\begin{array}{l}\text { Водоснабжение; водоотведение, } \\
\text { организация сбора и утилизации } \\
\text { отходов, деятельность по ликви- } \\
\text { дации загрязнений }\end{array}$ & & & -8 & - \\
\hline \multicolumn{2}{|c|}{$\begin{array}{l}\text { Объем отгруженных товаров собственного произ- } \\
\text { водства, выполненных работ и услуг собственными } \\
\text { силами на душу населения }\end{array}$} & 4-e & $31-e$ & +27 & + \\
\hline \multicolumn{2}{|c|}{ Продукция сельского хозяйства } & 77 -e & 89 -e & +12 & + \\
\hline \multicolumn{2}{|c|}{ Ввод в действие жилых домов на 1000 чел. населения } & $85-\mathrm{e}$ & $81-\mathrm{e}$ & -4 & - \\
\hline \multicolumn{2}{|c|}{ Оборот розничной торговли на душу населения } & 19 -e & $35-\mathrm{e}$ & +16 & + \\
\hline \multicolumn{2}{|c|}{ Среднедушевые денежные доходы в месяц } & 4-e & 9 -e & +5 & + \\
\hline \multicolumn{2}{|c|}{$\begin{array}{l}\text { Среднемесячная номинальная заработная плата ра- } \\
\text { ботников организаций }\end{array}$} & $2-e$ & 8 -e & +6 & + \\
\hline \multicolumn{2}{|l|}{ Уровень занятости } & 4-e & $6-e$ & +2 & + \\
\hline \multicolumn{2}{|c|}{ Уровень безработицы } & $46-\mathrm{e}$ & $33-e$ & -13 & + \\
\hline \multicolumn{2}{|c|}{$\begin{array}{l}\text { Общая площадь жилых помещений, приходящаяся } \\
\text { в среднем на одного жителя }\end{array}$} & $8-e$ & $2-e$ & -6 & - \\
\hline \multicolumn{2}{|c|}{$\begin{array}{l}\text { Численность студентов, обучающихся по программам } \\
\text { высшего образования, на } 10000 \text { чел. населения }\end{array}$} & 48 -e & $6-e$ & -42 & - \\
\hline
\end{tabular}

* На 01.01.2018 г.

** На 01.01.2008 г

***Данные за 9 мес 2018 г.

Составлено по данным Статистического сборника «Регионы России» [Электрон. pecypc]. http://www.gks.ru/wps/wcm/ connect/rosstat_main/rosstat/ru/statistics/publications/catalog/doc_1138623506156.

Вследствие снижения численности населения по-прежнему остается высоким в регионе уровень занятости (4-е место в 2018 г.). Проводимые реформы, результатом которых, в том числе, является оптимизация штатной численности (сокращение персонала), подталкивают постоянное население региона к переезду в другие (несеверные) регионы. Это позволило региону улучшить показатель, оценивающий уровень безработицы, и переместиться с 33-го места в 2007 г. на 46-е.
По показателю «Объем отгруженных товаров собственного производства, выполненных работ и услуг собственными силами» в 2007 г. регион занимал 70-е место, в 2018 г. - 69-е. Положительная динамика прослеживается по показателю «Объем отгруженных товаров собственного производства, выполненных работ и услуг собственными силами по виду экономической деятельности «добыча полезных ископаемых» - область переместилась с 27-го на 21-е место. Отметим, что этот вид деятельности основной для региона. 
Базовой отраслью является добыча благородHblх металлов - золота и серебра. Несмотря на нестабильный объем добычи, ее доля в структуре промышленного производства составляет 57-84\%. Основная особенность развития - монопрофильность ресурсной экономики. Ухудшение горно-геологических условий разработки месторождений россыпного золота, продолжающейся уже более 80 лет, привело к существенному снижению объемов его добычи. В результате за 2000-2018 гг. Магаданская область с 1-го места в рейтинге золотодобывающих регионов России (2000-2002 гг.) переместилась на 4-е в 2014 г. Тогда компенсирующим фактором в поддержании промышленного производства региона явилось масштабное наращивание добычи серебра: в последние годы Магаданская область стала крупнейшим производителем серебра в России. По итогам 2018 г. в регионе добыча серебра составила 696.4 т $(62.2 \%$ от общероссийского объема добычи серебра). В связи с увеличением рудной добычи золота по итогам 2018 г. регион занимает 2-е место (36.8 т - 14\% общероссийской добычи) в рейтинге золотодобывающих регионов России после Красноярского края.

Рыбохозяйственный комплекс Магаданской области за оцениваемый период характеризуется положительной динамикой. Усилиями государства и ведущих предприятий отрасли расширяется ресурсная база рыболовства, ведется интенсивная промысловая разведка и успешное освоение новых промысловых видов, увеличивается объем квот. Количество предприятий и индивидуальных предпринимателей, занятых в освоении этих видов, увеличилось в 2 раза (с 35 в 2007 г. до 72 в 2018 г.). Объем реализации продукции магаданскими предприятиями за прошедшие 11 лет вырос практически в 2 раза. Производительность труда в отрасли за этот период увеличилась с 33 до 55 т на одного работающего. Следствием успешной работы рыбной отрасли в Магаданской области ежегодно является высокий уровень среднедушевого потребления рыбопродукции, он находится в пределах 35-37 кг (норма потребительской корзины для трудоспособного населения региона - 35.1 кг), значительно опережая среднероссийский показатель (21.7 кг, при норме потребительской корзины для трудоспособного населения 22 кг).

По виду экономической деятельности «Обрабатывающие производства» регион в общероссийском рейтинге переместился с 74-го на 78-е место. По показателю «Продукция сельского хозяйства» регион находится на 77-м месте.

По удельному весу автомобильных дорог с твердым покрытием в общей протяженности автомобильных дорог общего пользования регион перешел из 4-го в 1-й десяток в рейтинге.
Магаданская область устойчиво сохраняет статус одного из лучших регионов по показателю «Среднедушевые денежные доходы в месяц» (4-е место) и «Среднемесячная номинальная заработная плата работников организаций» (2-е место). И в то же время имеет хронический статус одного из худших регионов по размерам миграции (коэффициент миграционной убыли): в 2007 г. - 1-е место, в 2018 г. - 4-е. Это объясняется низкой покупательной способностью среднедушевых доходов населения (отношением среднедушевого дохода к прожиточному минимуму в регионе): 3.52 в 2017 г. при среднероссийском уровне 3.66. В 1991 г. среднедушевые доходы в Магаданской области обеспечивали 5 прожиточных минимумов, в 2018 г. - только 3 (Гальцева и др., 2017).

Регион продолжает оставаться финансово несамостоятельным. По доле безвозмездных поступлений в доходах консолидированного бюджета субъектов как в 2007 г., так и в 2018 г. он занимает 19-е место. Доля дотаций находится в диапазоне от 32 до $56 \%$.

В состав Магаданской области входят город областного значения и 8 районов, в границах которых с 2014 г. образованы 9 городских округов*, отличающихся по площади, численности и плотности населения, специализации и уровню социально-экономического развития. Так, площадь территории районов варьирует от 19.2 (Хасынский район) до 102 тыс. км² (СевероЭвенский район) (табл. 2), удельный вес безвозмездных поступлений в доходах бюджетов муниципальных районов - от 51 (Тенькинский район) до 87\% (Северо-Эвенский район).

Численность населения по состоянию на 01.01 .2019 г. по районам колеблется от 1.9 (Северо-Эвенский район) до 9.6 тыс. чел. (Ольский район), в г. Магадане проживает 98.7 тыс. чел. (рис. 2). С 2007 г. численность населения районов заметно уменьшилась. Так, Среднеканский, Тенькинский и Ягоднинский районы потеряли около 40\% населения, Северо-Эвенский и Сусуманский - более $30 \%$, Хасынский - 23\%, Омсукчанский и Ольский - 14 и $12 \%$ соответственно. Население г. Магадана уменьшилось на $8 \%$ (см. рис. 2).

\footnotetext{
*Территориальная организация местного самоуправления в Магаданской области установлена Конституцией РФ, Федеральным Законом от 06.11.2013 № 131-Ф3 «Об общих принципах организации местного самоуправления в Российской Федерации» и соответствующими Законами Магаданской области; Постановление администрация Магаданской области от 11 апреля 2013 г. № 305-па «Об утверждении реестра административно-территориальных единиц Магаданской области» (с изменениями на 12 августа 2019 г.) [Электрон. pecypc]. http://docs.cntd.ru/document/453377502
} 
Таблица 2. Общие сведения по районам Магаданской области

Table 2. General information on districts of Magadan Oblast

\begin{tabular}{|c|c|c|c|c|c|c|c|}
\hline \multirow[b]{2}{*}{$\begin{array}{c}\text { Район } \\
\text { (городской округ) }\end{array}$} & \multirow[b]{2}{*}{$\begin{array}{c}\text { Дата } \\
\text { образования }\end{array}$} & \multirow[b]{2}{*}{ Районный центр } & \multirow{2}{*}{\begin{tabular}{|} 
Площадь \\
террито- \\
рии \\
района, \\
тыс. км²
\end{tabular}} & \multirow{2}{*}{$\begin{array}{c}\text { Расстоя- } \\
\text { ние } \\
\text { до } \\
\text { област- } \\
\text { ного } \\
\text { центра, } \\
\text { км* }\end{array}$} & \multirow{2}{*}{$\begin{array}{c}\text { Доля действую- } \\
\text { щих населенных } \\
\text { пунктов } \\
\text { в общем числе } \\
\text { административно- } \\
\text { территориальных } \\
\text { единиц района, \% }\end{array}$} & \multicolumn{2}{|c|}{$\begin{array}{c}\text { Численность } \\
\text { населения, тыс. чел. }\end{array}$} \\
\hline & & & & & & $\begin{array}{c}\text { на } \\
01.01 .2008 \text { г. }\end{array}$ & $\begin{array}{c}\text { на } \\
01.01 .2019 \text { г. }\end{array}$ \\
\hline г. Магадан & 14.07.1939 г. & - & 1.2 & - & 100 & 107.1 & 98.7 \\
\hline Ольский & 04.01.1926 г. & пос. Ола & 75.8 & 35 & 100 & 11.0 & 9.6 \\
\hline Омсукчанский & 16.07.1954 г. & пос. Омсукчан & 60.4 & 576 & 50 & 5.7 & 4.9 \\
\hline Северо-Эвенский & 09.07.1931 г. & пос. Эвенск & 102.0 & 535 & 100 & 2.8 & 1.9 \\
\hline Среднеканский & $23.08 .1931 \Gamma$ & пос. Сеймчан & 91.8 & 493 & 33 & 3.6 & 2.2 \\
\hline Сусуманский & 02.12.1953 г. & г. Сусуман & 46.8 & 635 & 54 & 10.2 & 7.1 \\
\hline Тенькинский & 02.12.1953 г. & пос. Усть-Омчуг & 35.6 & 264 & 40 & 6.1 & 3.6 \\
\hline Хасынский & 30.12.1966 г. & пос. Палатка & 19.3 & 82 & 35 & 8.1 & 6.2 \\
\hline Ягоднинский & 02.12.1953 г. & пос. Ягодное & 29.6 & 528 & 50 & 11.2 & 6.9 \\
\hline
\end{tabular}

* Расстояние от районных центров до г. Магадана приведено наземным путем, от пос. Эвенск - воздушным.

Источник: Областной центр и районы Магаданской области. Статистический сборник. Магадан : Магаданстат, 2008. 170 с.; Данные Управления федеральной службы государственной статистики по Хабаровскому краю, Магаданской области, Еврейской автономной области и Чукотскому автономному округу [Электрон. pecypc]. https://habstat.gks.ru/

Демографическая ситуация постперестроечного периода характеризуется, наряду с массовым оттоком населения из Магаданской области, «стягиванием» оставшегося в г. Магадан, что является особенностью многих северных регионов и характерной чертой процесса метрополизации как разнопланового доминирования ведущего пространственного ареала над подчиненной территорией, носящего субъективно-объективный характер (Кузин, 2019).

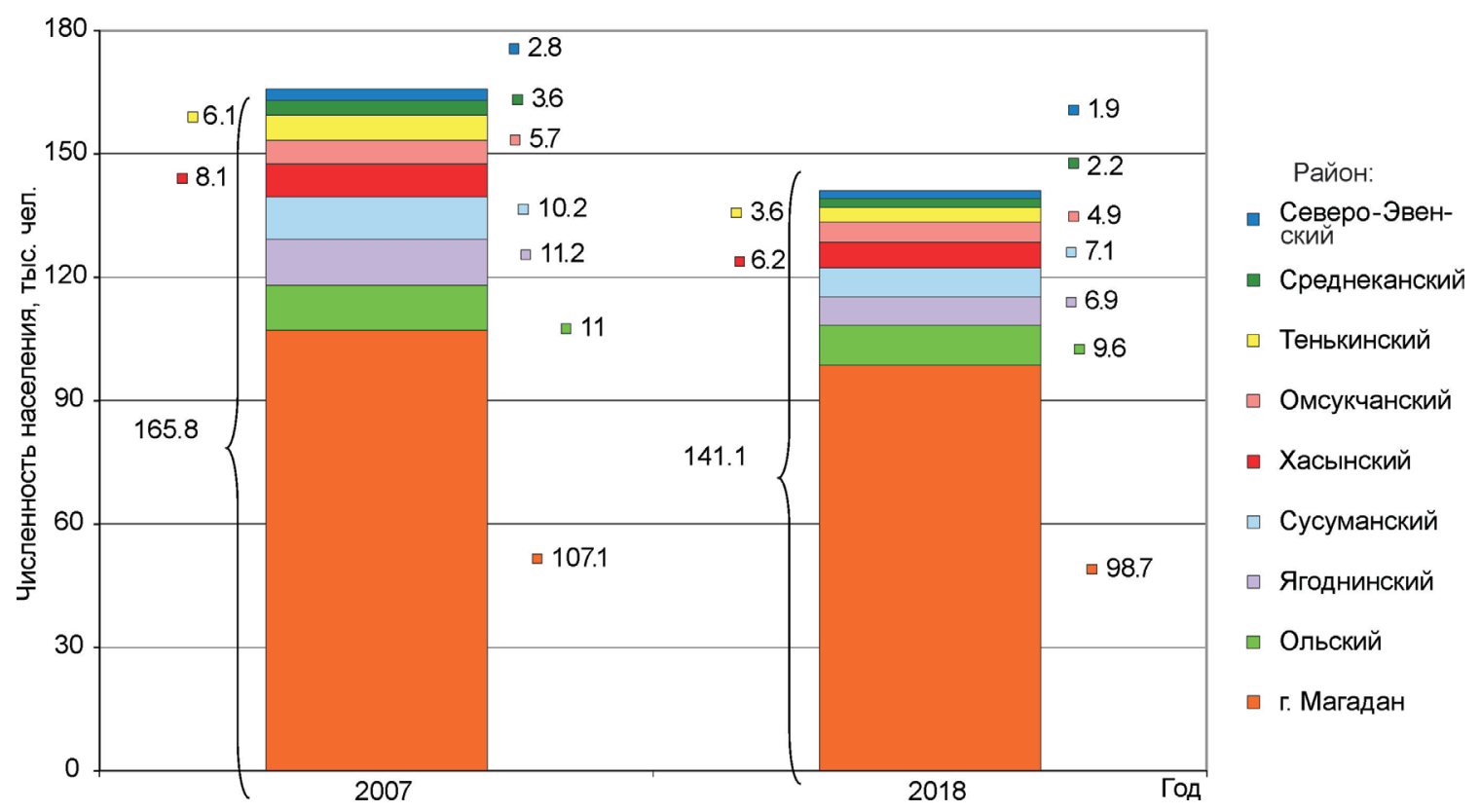

Puc. 2. Численность населения по районам Магаданской области в 2007 и 2018 г., тыс. чел. (Источник: Областной центр и районы Магаданской области. Статистический сборник. Магадан : Магаданстат, 2008.170 с.; Данные Управления федеральной службы государственной статистики по Хабаровскому краю, Магаданской области, ЕАО и ЧАО [Электрон. pecypc]. https://habstat.gks.ru/)

Fig. 2. Population by districts of Magadan Oblast in 2007 and 2018, K persons (Sources: Administrative Center and Districts of Magadan Oblast: Selected Statistics. Magadan : Magadanstat, 2008. 170 p.; Data of the Federal Statistic Service for Khabarovsk Krai, Magadan Oblast, Jewish Autonomous Oblast, and Chukotka Autonomous Okrug. https:// habstat.gks.ru/) 
Таблица 3.Специализация районов Магаданской области

Table 3. Specialization of Magadan Oblast districts

\begin{tabular}{|c|c|c|c|c|c|c|c|c|c|c|c|c|c|c|c|c|c|c|}
\hline \multirow{3}{*}{$\begin{array}{c}\text { Район / городской } \\
\text { округ }\end{array}$} & \multicolumn{18}{|c|}{ Вид экономической деятельности } \\
\hline & \multicolumn{2}{|c|}{$\begin{array}{c}\text { Добыча } \\
\text { полезных } \\
\text { ископа- } \\
\text { емых, } \\
\text { кроме } \\
\text { топливно- } \\
\text { энергети- } \\
\text { ческих }\end{array}$} & \multicolumn{2}{|c|}{$\begin{array}{c}\text { Добыча } \\
\text { топливно- } \\
\text { энергети- } \\
\text { ческих } \\
\text { полезных } \\
\text { ископае- } \\
\text { мых }\end{array}$} & \multicolumn{2}{|c|}{$\begin{array}{c}\text { Обраба- } \\
\text { тывающие } \\
\text { производ- } \\
\text { ства }\end{array}$} & \multicolumn{3}{|c|}{$\begin{array}{c}\text { Производ- } \\
\text { ство и рас- } \\
\text { пределение } \\
\text { электро- } \\
\text { энергии } \\
\text { и воды }\end{array}$} & \multicolumn{3}{|c|}{$\begin{array}{l}\text { Рыболов- } \\
\text { ство и ры- } \\
\text { боводство }\end{array}$} & \multicolumn{2}{|c|}{$\begin{array}{l}\text { Сельское } \\
\text { хозяйство }\end{array}$} & \multicolumn{2}{|c|}{$\begin{array}{c}\text { Транспорт } \\
\text { и связь }\end{array}$} & \multicolumn{2}{|c|}{$\begin{array}{c}\text { Строитель- } \\
\text { ство }\end{array}$} \\
\hline & $\hat{\stackrel{े}{\imath}}$ & $\stackrel{\infty}{\stackrel{i}{i}}$ & $\hat{\text { ¿े }}$ & $\stackrel{\infty}{\stackrel{2}{2}}$ & $\hat{\text { ¿ }}$ & $\frac{\infty}{\bar{\tau}}$ & & 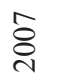 & $\stackrel{\infty}{\stackrel{i}{\sim}}$ & $\hat{c}$ & & $\frac{\infty}{2}$ & $\hat{\&}$ & $\stackrel{\infty}{\stackrel{n}{*}}$ & $\hat{\text { ¿ }}$ & $\stackrel{\infty}{\stackrel{\sim}{*}}$ & $\hat{\tilde{丶}}$ & $\stackrel{\infty}{\stackrel{i}{*}}$ \\
\hline г. Магадан & & & & & & & & & & & & & & & & & & \\
\hline Ольский & & & & & & & & & & & & & & & & & & \\
\hline Омсукчанский & & & & & & & & & & & & & & & & & & \\
\hline Северо-Эвенский & & & & & & & & & & & & & & & & & & \\
\hline Среднеканский & & & & & & & & & & & & & & & & & & \\
\hline Сусуманский & & & & & & & & & & & & & & & & & & \\
\hline Тенькинский & & & & & & & & & & & & & & & & & & \\
\hline Хасынский & & & & & & & & & & & & & & & & & & \\
\hline Ягоднинский & & & & & & & & & & & & & & & & & & \\
\hline
\end{tabular}

Источник: Областной центр и районы Магаданской области. Стат. сборник. Магадан : Магаданстат, 2008. 170 с.; Данные Управления федеральной службы государственной статистики по Хабаровскому краю, Магаданской области, ЕАО и ЧАО [Электрон. pecypc]. https://habstat.gks.ru/

$a$

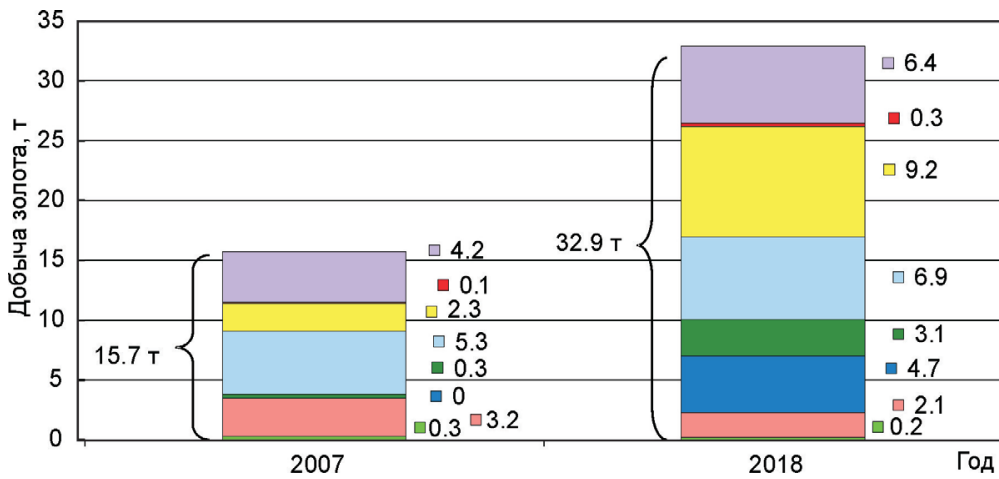

Район:

$\square$ Ягоднинский

- Хасынский

$\square$ Тенькинский

- Сусуманский

- Среднеканский

- Северо-Эвенский

- Омсукчанский

๑льский $\sigma$

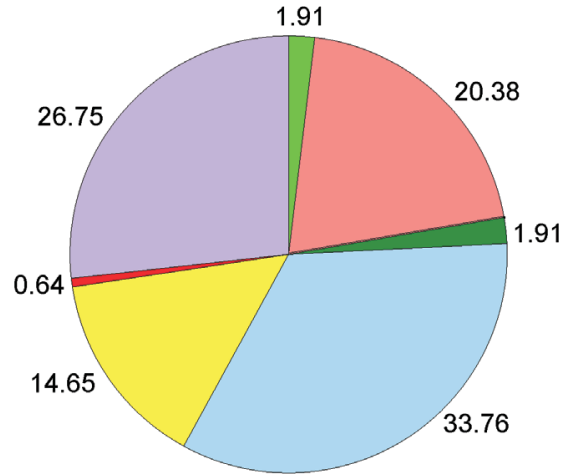

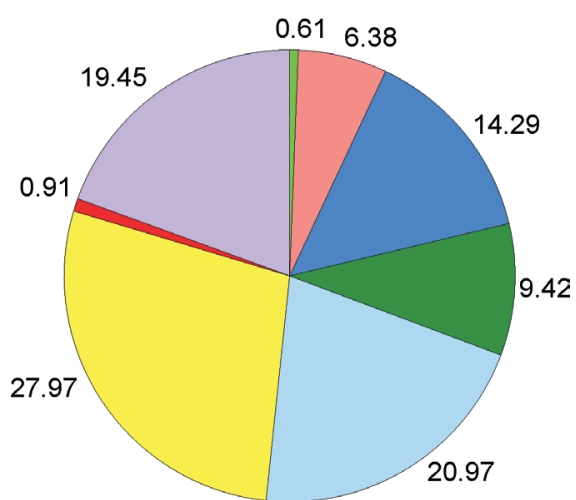

Puc. 3. Добыча золота по районам Магаданской области в 2007 и 2018 г:: $a$ - в тоннах, $\sigma$ - в \% от общеобластного уровня (Источник: Минерально-сырьевые ресурсы Магаданской области: перспективы развития: Аналитическая информация. Магадан: Магаданстат, 2009. 33 с.; Данные Министерства природных ресурсов и экологии Магаданской области)

Fig. 3. Gold production by districts of Magadan Oblast in 2007 and 2018: $a$ - tons, $\sigma-\%$ of the general level in Magadan Oblast (Source: Mineral Resources of Magadan Oblast: Perspectives for Development. Analytical Information. Magadan, Magadanstat, 2009. 33 p.; Data from Magadan Oblast Ministry for Natural Resources and Ecology) 
Однако для г. Магадана процесс метрополизации выражен лишь в концентрации промышленных, финансовых и культурных функций, но не в быстром росте населения. Поскольку, даже несмотря на внутрирегиональную миграцию населения из районов в областной центр, г. Магадан характеризуется ежегодным отрицательным миграционным сальдо.

Во многих районах вызывает тревогу низкая доля действующих населенных пунктов в общем числе административно-территориальных единиц. Лишь в Магадане, Ольском и СевероЭвенском районах все административно-территориальные единицы являются действующими (см. табл. 2). В остальных районах имеются заброшенные, упраздненные или закрывающиеся населенные пункты, в том числе с численностью населения 10 чел. и менее.

Уровень социально-экономического положения муниципальных образований во многом определяет районная специализация. Если говорить обо всех видах деятельности, занимающих в общем объеме производства товаров и услуг основную долю (более 20\%), районы можно классифицировать, как показано в табл. 3.

В 2018 г. изменилась специализация в ряде районов. Так, в Среднеканском районе в связи с запуском работы Усть-Среднеканской ГЭС (в 2013 г.), к доминирующим видам деятельности добавилось «производство и распределение электроэнергии и воды». В Северо-Эвенском районе в связи с добычей золота основным видом экономической деятельности, помимо рыбодобычи, стала «добыча полезных ископа-емых».

Поскольку основная специализация Магаданской области в целом - это добыча золота, оценим, как изменился вклад каждого района в общеобластной объем добычи (рис. 3).

В 2007 г. основная доля продукции добывающих производств, и в частности золота, была получена на территории Омсукчанского и Сусуманского районов. Объем добычи золота в целом по области за анализируемый период увеличился вдвое, благодаря наращиванию добычи россыпного золота в Ягоднинском и Сусуманском районах, а также освоению рудных месторождений в Тенькинском и Северо-Эвенском районах. В 2018 г. в лидеры вышел Тенькинский район вследствие освоения рудных месторождений 3олота Павлик и Наталка, 2-е место по золотодобыче сохранил Сусуманский район, Ягоднинский с 1-го места переместился на 3-е.

Рейтинг районов области по уровню социально-экономического положения проведен по 3 группам показателей на основе статистических данных за 2007 и 2018 г.

К первой группе отнесены показатели, характеризующие состояние производственной сферы территории (объем отгруженной продукции по видам экономической деятельности, объем инвестиций в основной капитал) (табл. 4).

Вторая группа включает показатели финансовой сферы (удельный вес прибыльных организаций в общем количестве организаций удельный вес безвозмездных поступлений в доходах бюджета, задолженность по выплате заработной платы, среднемесячная номинальная начисленная заработная плата) (табл. 5).

Третью группу составляют относительные показатели, характеризующие состояние социальной сферы (миграционный прирост, отток (-) населения на 10 тыс. чел., объем платных услуг населению, средняя обеспеченность населения жильем, врачами, уровень безработицы) (табл. 6).

На начальном этапе ранжируем районы области по каждому показателю, входящему в соответствующую группу. Далее определяем рейтинг по группе как среднее арифметическое рангов по каждому показателю, входящему в группу.

Так, по группе показателей производственной сферы в тройку лидеров в 2007 г. вошли г. Магадан, Ягоднинский и Сусуманский районы, в 2018 г. - Ягоднинский район, г. Магадан, Омсукчанский район (см. табл. 4). Причем город преимущественно лидирует по объему продукции обрабатывающих производств, производства и распределения электроэнергии и воды, в объеме инвестиций в основной капитал. Районы же являются лидерами по объему производства добывающей отрасли, в частности за счет добычи золота и серебра. Заметны перемены по данной группе показателей за оцениваемый период в СевероЭвенском районе на фоне роста золотодобычи на территории муниципального образования.

В финансовой сфере по результатам рейтинга за оцениваемый период 1-е место удержал Омсукчанский район, затем следуют г. Магадан и Сусуманский район (см. табл. 5). Ольский район демонстрирует ухудшение в рейтинге, переместившись с 4-го на 9-е место, здесь самая высокая доля дотаций районного бюджета среди муниципальных образований региона и самый низкий уровень заработной платы. Финансовое благополучие Омсукчанского и Сусуманского районов обеспечивается деятельностью градообразующих горнодобывающих компаний AO «Полиметалл» (добыча серебра и золота на месторождениях Дукат, Лунное, Гольцовое) и золотодобывающей компании ПАО «Сусуманзолото» (добыча рудного золота, отработка россыпных месторождений, причем открытым, дражным и подземным способами). Высокие производственные показатели предприятий позволяют наполнять районный бюджет значительными налоговыми поступлениями и создавать высокооплачиваемые рабочие места. 

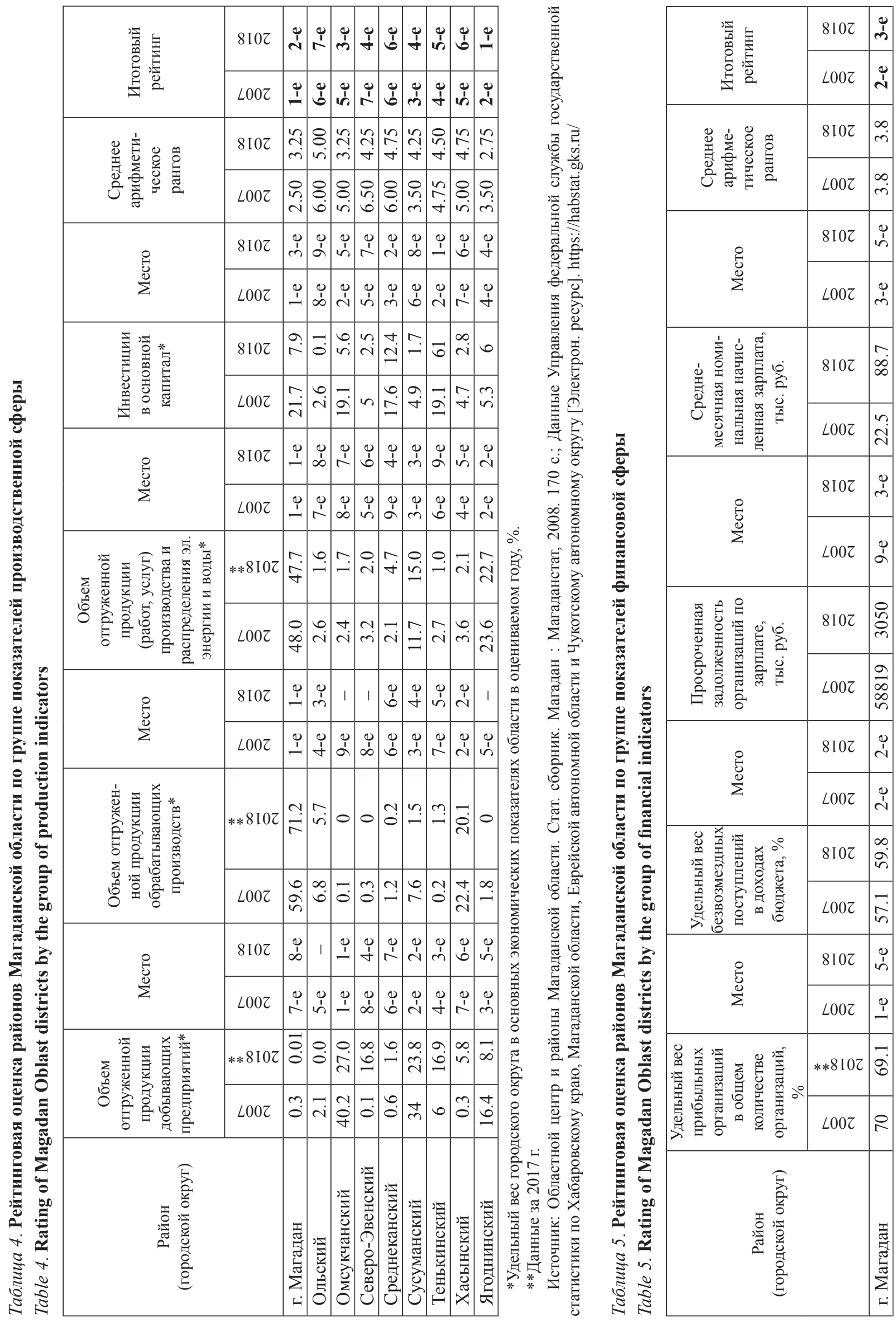


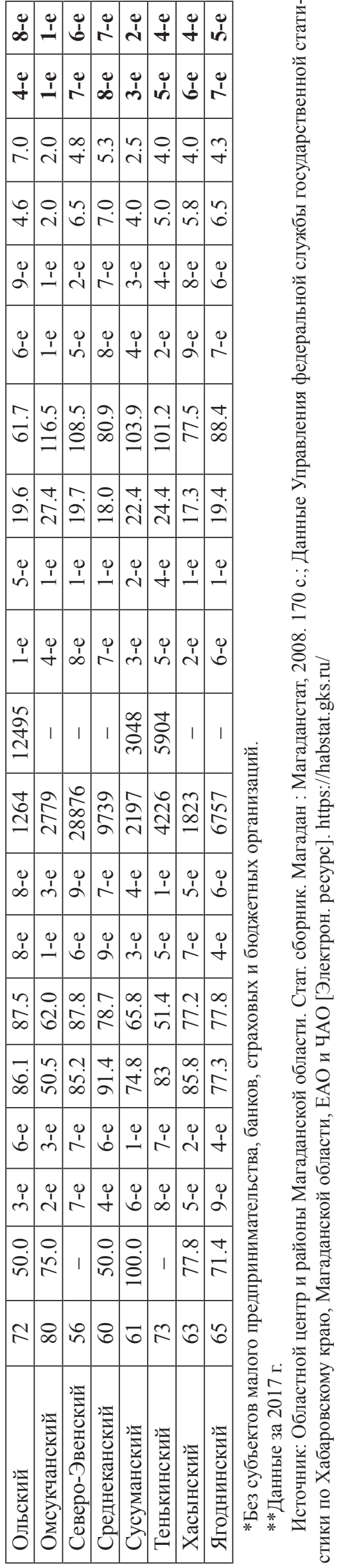

\begin{tabular}{|c|c|c|c|c|c|c|c|c|c|c|c|}
\hline \multirow{2}{*}{ 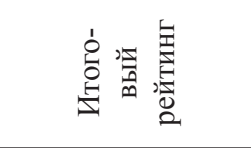 } & $8 \mathrm{I} 0 \mathrm{Z}$ & İ & a & ì & i & $\begin{array}{l}0 \\
0 \\
1 \\
1\end{array}$ & $\mid$ & D. & $\left|\begin{array}{c}i \\
\Lambda\end{array}\right|$ & లు & 욜 \\
\hline & $\angle 00 Z$ & i & i & $\stackrel{d}{1}$ & D. & bً & $\begin{array}{c}0 \\
\vdots \\
\sim\end{array}$ & חי̃ & $\begin{array}{l}0 \\
\dot{I} \\
\end{array}$ & $\begin{array}{l}\dot{I} \\
\dot{t}\end{array}$ & \\
\hline \multirow{2}{*}{ 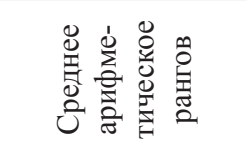 } & $8 \mathrm{I} 0 \mathrm{Z}$ & $\begin{array}{l}\stackrel{0}{i} \\
\stackrel{i}{*}\end{array}$ & $\stackrel{\circ}{\circ}$ & $\stackrel{\infty}{+}$ & $\begin{array}{l}0 \\
\dot{v}\end{array}$ & $\stackrel{0}{\dot{r}}$ & $\begin{array}{c}n \\
n \\
n\end{array}$ & $\stackrel{\infty}{0}$ & $\left|\begin{array}{l}\infty \\
\dot{r}\end{array}\right|$ & $\stackrel{\sim}{\sim}$ & \\
\hline & $\angle 00 Z$ & $\begin{array}{l}0 \\
\dot{i}\end{array}$ & $\stackrel{0}{r}$ & $\stackrel{\sim}{\sim}$ & $\stackrel{N}{N}$ & $\begin{array}{l}0 \\
\dot{n}\end{array}$ & $\begin{array}{c}\sim \\
m\end{array}$ & $\begin{array}{l}0 \\
i\end{array}$ & $\underset{\nabla}{+}$ & $\stackrel{\nabla}{r}$ & \\
\hline \multirow{2}{*}{$\begin{array}{l}\text { : } \\
\sum_{2}^{\infty}\end{array}$} & $8 \mathrm{I} 0 \mathrm{Z}$ & i & 童 & $\begin{array}{c}0 \\
\vdots \\
\end{array}$ & $\begin{array}{l}0 \\
1 \\
a\end{array}$ & $\begin{array}{l}0 \\
\\
n\end{array}$ & $\mid \begin{array}{l}0 \\
\dot{T} \\
\dot{t}\end{array}$ & $\begin{array}{r}0 \\
i \\
i\end{array}$ & $\mid \begin{array}{c}0 \\
1 \\
m\end{array}$ & $\begin{array}{l}0 \\
b \\
b\end{array}$ & \\
\hline & $\angle 00 Z$ & $\stackrel{i}{I}$ & $\begin{array}{c}0 \\
1 \\
\infty\end{array}$ & $\begin{array}{c}i \\
\stackrel{\sim}{\sim}\end{array}$ & $\begin{array}{l}i \\
i \\
i\end{array}$ & $\begin{array}{c}0 \\
⿱ \\
m\end{array}$ & $\mid \begin{array}{l}0 \\
\dot{T} \\
\dot{T}\end{array}$ & $\begin{array}{l}0 \\
⿱ \\
n\end{array}$ & $\mid \begin{array}{l}0 \\
\dot{m} \\
m\end{array}$ & $\begin{array}{l}0 \\
b \\
b\end{array}$ & \\
\hline \multirow{2}{*}{ 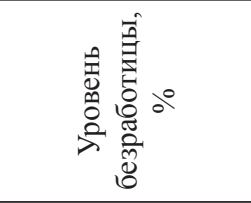 } & $8 \mathrm{I} 0 \mathrm{Z}$ & $\stackrel{\stackrel{\Im}{\ddagger}}{\circ}$ & $\begin{array}{l}\vec{b} \\
i\end{array}$ & $\begin{array}{l}\dot{\sigma} \\
\stackrel{0}{0}\end{array}$ & $\begin{array}{l}\infty \\
\stackrel{\sim}{1} \\
\end{array}$ & $\stackrel{\overbrace{}}{\stackrel{-}{-}}$ & $\vec{\sim}$ & $\stackrel{\substack{f \\
i}}{i}$ & $\mid \begin{array}{l}\infty \\
0 \\
-\end{array}$ & $\underset{\infty}{-}$ & \\
\hline & $\angle 00 Z$ & $\stackrel{\sim}{-}$ & $\stackrel{ \pm}{ \pm}$ & $\exists$ & กิ & $\vec{m}$ & $\stackrel{m}{\sim}$ & $\dot{F}$ & $\vec{m}$ & $\begin{array}{l}6 \\
\dot{n}\end{array}$ & \\
\hline \multirow{2}{*}{$\begin{array}{l}\text { \&्. } \\
\sum^{\infty}\end{array}$} & $8 \mathrm{I} 0 \mathrm{Z}$ & $\begin{array}{l}0 \\
\\
-1\end{array}$ & 变 & $\begin{array}{c}\dot{1} \\
i\end{array}$ & $\begin{array}{l}\dot{1} \\
\sim\end{array}$ & $\begin{array}{r}0 \\
+ \\
t\end{array}$ & $\mid \begin{array}{l}0 \\
i \\
i\end{array}$ & $\begin{array}{l}0 \\
\alpha \\
a\end{array}$ & $\begin{array}{l}0 \\
i \\
1\end{array}$ & $\begin{array}{c}\dot{d} \\
\dot{m}\end{array}$ & \\
\hline & $\angle 00 Z$ & 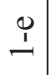 & $\begin{array}{c}0 \\
1 \\
\infty\end{array}$ & $\begin{array}{c}\dot{1} \\
\grave{n}\end{array}$ & $\begin{array}{l}\dot{I} \\
\dot{t}\end{array}$ & $\stackrel{i}{i}$ & $\mid \begin{array}{c}0 \\
i \\
n\end{array}$ & $\begin{array}{l}0 \\
1 \\
b\end{array}$ & $\begin{array}{c}i \\
\dot{1} \\
a\end{array}$ & $\begin{array}{l}\stackrel{i}{1} \\
\sim\end{array}$ & \\
\hline \multirow{2}{*}{ 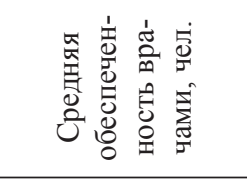 } & $* 8 \mathrm{I} 0 \mathrm{Z}$ & $\begin{array}{l}0 \\
\stackrel{2}{2}\end{array}$ & $\stackrel{m}{m}$ & $\begin{array}{l}\stackrel{0}{\dot{q}} \\
\end{array}$ & $\vec{b}$ & $\begin{array}{l}\hat{\dot{b}} \\
\ddot{n}\end{array}$ & $\begin{array}{c}\overrightarrow{\dot{m}} \\
\vec{m}\end{array}$ & $\begin{array}{l}n \\
i \\
n \\
m\end{array}$ & $\overrightarrow{\stackrel{r}{m}}$ & $\overrightarrow{8}$ & \\
\hline & $\angle 00 Z$ & àd & ते & $\frac{q}{\dot{\gamma}}$ & ले & $\overrightarrow{\dot{m}}$ & $\begin{array}{l}n \\
m \\
m\end{array}$ & $\frac{m}{m}$ & $\begin{array}{l}n \\
\tilde{n}\end{array}$ & $\begin{array}{l}\forall \\
\dot{q}\end{array}$ & \\
\hline \multirow{2}{*}{ 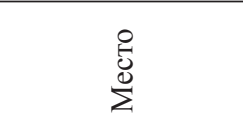 } & $8 \mathrm{I} 0 \mathrm{Z}$ & $\begin{array}{l} \\
0 \\
0\end{array}$ & \begin{tabular}{|c|} 
\\
\\
$\infty$
\end{tabular} & $\begin{array}{l}i \\
i \\
i\end{array}$ & \begin{tabular}{|l|} 
\\
0 \\
$b$
\end{tabular} & $\begin{array}{l}0 \\
1 \\
n \\
n\end{array}$ & \begin{tabular}{|c|} 
\\
$i$ \\
$i$
\end{tabular} & $\begin{array}{l} \\
\dot{q}\end{array}$ & \begin{tabular}{|c|}
$\dot{1}$ \\
$\dot{m}$ \\
\end{tabular} & $\stackrel{.}{I}$ & \\
\hline & $\angle 00 Z$ & $\begin{array}{l}0 \\
1 \\
a\end{array}$ & $\begin{array}{c}0 \\
i \\
i\end{array}$ & $\begin{array}{l}0 \\
b\end{array}$ & $\begin{array}{c}0 \\
1 \\
\infty \\
0\end{array}$ & 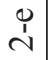 & i & $\begin{array}{l}0 \\
\dot{n} \\
\end{array}$ & $\mid \begin{array}{c}0 \\
\dot{t}\end{array}$ & $\begin{array}{c}0 \\
\dot{m} \\
m\end{array}$ & \\
\hline \multirow{2}{*}{ 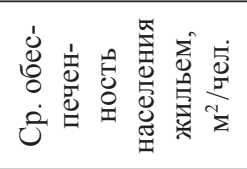 } & $8 \mathrm{IOZ}$ & $\begin{array}{c}\sim \\
i \\
i\end{array}$ & $\stackrel{i}{\hat{v}}$ & $\begin{array}{l}0 \\
\ddot{\lambda}\end{array}$ & $\begin{array}{l}a \\
\dot{n} \\
\dot{m}\end{array}$ & $\stackrel{\grave{m}}{\grave{m}}$ & \begin{tabular}{|c|}
$\vec{f}$ \\
\end{tabular} & $\begin{array}{l}+ \\
\dot{q}\end{array}$ & $\begin{array}{l}0 \\
\dot{g} \\
\dot{q} \\
\end{array}$ & $\begin{array}{l}0 \\
\dot{n} \\
\end{array}$ & \\
\hline & $\angle 00 z$ & $\hat{\tilde{N}}$ & $\stackrel{\infty}{\sim}$ & $\begin{array}{l}m \\
\infty \\
i \\
\sim\end{array}$ & $\begin{array}{l}\infty \\
\sim \\
\sim \\
\end{array}$ & $\frac{\vartheta}{\dot{\gamma}}$ & \begin{tabular}{|l|}
$\infty$ \\
$\mathcal{I}$ \\
\end{tabular} & $\begin{array}{l}0 \\
\dot{2}\end{array}$ & $\begin{array}{l}\hat{\sigma} \\
\dot{0} \\
m\end{array}$ & $\begin{array}{l}\vec{j} \\
\dot{q} \\
\end{array}$ & \\
\hline \multirow{2}{*}{$\begin{array}{l}\text { 足 } \\
\sum^{\infty}\end{array}$} & $8 \mathrm{I} 0 \mathrm{Z}$ & $\begin{array}{c}0 \\
i \\
-1\end{array}$ & $\begin{array}{r}0 \\
1 \\
\infty \\
\end{array}$ & $\begin{array}{l}0 \\
b \\
b\end{array}$ & $\begin{array}{l}1 \\
1 \\
a\end{array}$ & $\begin{array}{c}\dot{D} \\
\grave{n}\end{array}$ & \begin{tabular}{|l|} 
\\
$i$ \\
\end{tabular} & $\begin{array}{l}0 \\
1 \\
i\end{array}$ & $\begin{array}{r}0 \\
i \\
ن\end{array}$ & $\begin{array}{r}0 \\
\dot{t} \\
\end{array}$ & \\
\hline & $\angle 00 Z$ & $\stackrel{i}{i}$ & $\begin{array}{c}i \\
i \\
i\end{array}$ & $\begin{array}{l}\dot{1} \\
\stackrel{1}{n}\end{array}$ & $\begin{array}{l}1 \\
1 \\
0\end{array}$ & $\begin{array}{l}0 \\
\vdots \\
\alpha\end{array}$ & $\left|\begin{array}{c}0 \\
n \\
m\end{array}\right|$ & $\begin{array}{l}0 \\
b\end{array}$ & $\begin{array}{l}0 \\
\dot{1} \\
\sim\end{array}$ & $\begin{array}{l}\dot{I} \\
\dot{t} \\
\end{array}$ & \\
\hline \multirow{2}{*}{ 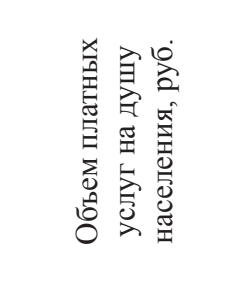 } & $* 8 \mathrm{I} 0 \mathrm{Z}$ & $\begin{array}{l}n \\
\tilde{i} \\
\tilde{\sigma} \\
\tilde{\sigma}\end{array}$ & 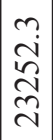 & $\begin{array}{l}0 \\
\dot{+} \\
\dot{f} \\
m\end{array}$ & 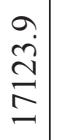 & $\begin{array}{l}m \\
\overrightarrow{0} \\
\stackrel{n}{\sigma}\end{array}$ & $\begin{array}{c}0 \\
i \\
\infty \\
\infty \\
\infty \\
\sim\end{array}$ & $\begin{array}{l}+ \\
\dot{0} \\
\dot{d} \\
\dot{w} \\
m\end{array}$ & $\begin{array}{c}\mathfrak{r} \\
\stackrel{\sim}{\tilde{S}} \\
\tilde{n}\end{array}$ & \begin{tabular}{|r}
0 \\
$\dot{8}$ \\
$\vdots$ \\
$\vdots$ \\
$\dot{q}$
\end{tabular} & \\
\hline & $\angle 00 Z$ & $\begin{array}{l}\stackrel{0}{\vec{d}} \\
\overrightarrow{\mathrm{D}} \\
\dot{\sigma}\end{array}$ & $\begin{array}{l}a \\
\hat{\sim} \\
\hat{q} \\
\dot{q}\end{array}$ & $\begin{array}{l}0 \\
0 \\
0 \\
0 \\
0 \\
-\end{array}$ & $\begin{array}{l}\infty \\
\dot{\tilde{j}} \\
2 \\
\end{array}$ & $\begin{array}{l}\overrightarrow{\dot{+}} \\
\stackrel{2}{\circ} \\
\stackrel{0}{0}\end{array}$ & 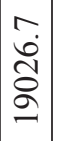 & 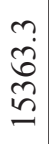 & 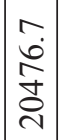 & $\begin{array}{c}0 \\
\dot{j} \\
\infty \\
\infty \\
\infty \\
-1 \\
\end{array}$ & \\
\hline \multirow{2}{*}{$\begin{array}{l}\stackrel{\circ}{0} \\
\sum_{\Sigma}^{\infty}\end{array}$} & $8 \mathrm{I} 0 \mathrm{Z}$ & 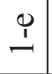 & $\begin{array}{c}1 \\
1 \\
m\end{array}$ & $\begin{array}{l}\stackrel{i}{7} \\
\dot{f}\end{array}$ & $\begin{array}{l}\stackrel{i}{1} \\
\stackrel{\sim}{\sim}\end{array}$ & $\begin{array}{l}0 \\
1 \\
\infty\end{array}$ & \begin{tabular}{|l|}
0 \\
$b$ \\
\end{tabular} & $\begin{array}{l}0 \\
1 \\
a\end{array}$ & $\begin{array}{c}0 \\
1 \\
n\end{array}$ & $\begin{array}{c}0 \\
1 \\
r\end{array}$ & \\
\hline & $\angle 00 Z$ & $\begin{array}{c}i \\
\text { I }\end{array}$ & $\begin{array}{r}\dot{1} \\
\mathbf{i}\end{array}$ & $\begin{array}{c}\dot{1} \\
i\end{array}$ & $\begin{array}{l}0 \\
a \\
a\end{array}$ & $\begin{array}{l}0 \\
\vdots \\
\infty\end{array}$ & $\begin{array}{l}0 \\
0 \\
b\end{array}$ & $\begin{array}{r}\dot{n} \\
\dot{m}\end{array}$ & $\begin{array}{c}\dot{I} \\
\dot{t}\end{array}$ & $\begin{array}{l}0 \\
i \\
i\end{array}$ & \\
\hline \multirow{2}{*}{ 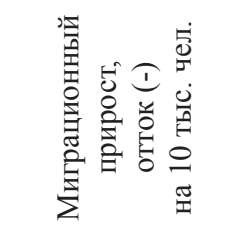 } & $* 8 \mathrm{I} 0 \mathrm{z}$ & $\begin{array}{c}\vec{n} \\
0 \\
-1\end{array}$ & 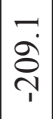 & 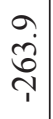 & $\begin{array}{c}\stackrel{a}{g} \\
\frac{g}{1}\end{array}$ & 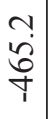 & $\mid \begin{array}{l}0 \\
\dot{n} \\
\vec{r} \\
\end{array}$ & $\underset{i}{\stackrel{\vec{P}}{\stackrel{P}{0}}}$ & $\begin{array}{l}0 \\
i \\
i \\
\tilde{r} \\
i\end{array}$ & $\begin{array}{c}+ \\
\tilde{n} \\
\stackrel{n}{\tau}\end{array}$ & \\
\hline & $\angle 00 Z$ & $\stackrel{m}{\oplus}$ & $\begin{array}{l}n \\
0 \\
+ \\
1 \\
\end{array}$ & 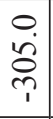 & 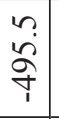 & $\begin{array}{l}\stackrel{\checkmark}{+} \\
\dot{f} \\
\dot{f}\end{array}$ & \begin{tabular}{|c|} 
\\
$\vec{n}$ \\
$\stackrel{n}{1}$ \\
\end{tabular} & 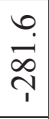 & \begin{tabular}{|c|}
$\infty$ \\
$\dot{+}$ \\
$\stackrel{+}{\sim}$ \\
$\uparrow$ \\
\end{tabular} & 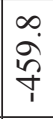 & \\
\hline \multicolumn{2}{|l|}{ 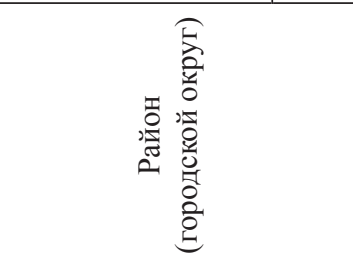 } & 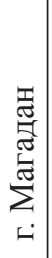 & 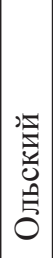 & 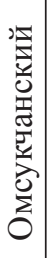 & 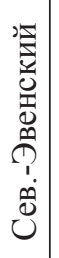 & 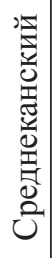 & 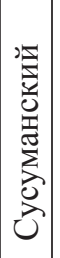 & 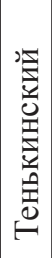 & 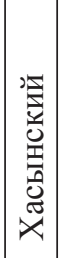 & 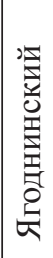 & \\
\hline
\end{tabular}


Финансовая стабильность г. Магадана во многом обусловлена территориальным расположением, развитой транспортной сферой, а также высокой концентрацией обслуживающих производств и сферы услуг.

Оценка социальных показателей (см. табл. 6) свидетельствует о лидирующих позициях областного центра, Сусуманского и Омсукчанского районов в 2007 г., являющихся одними из наибо-
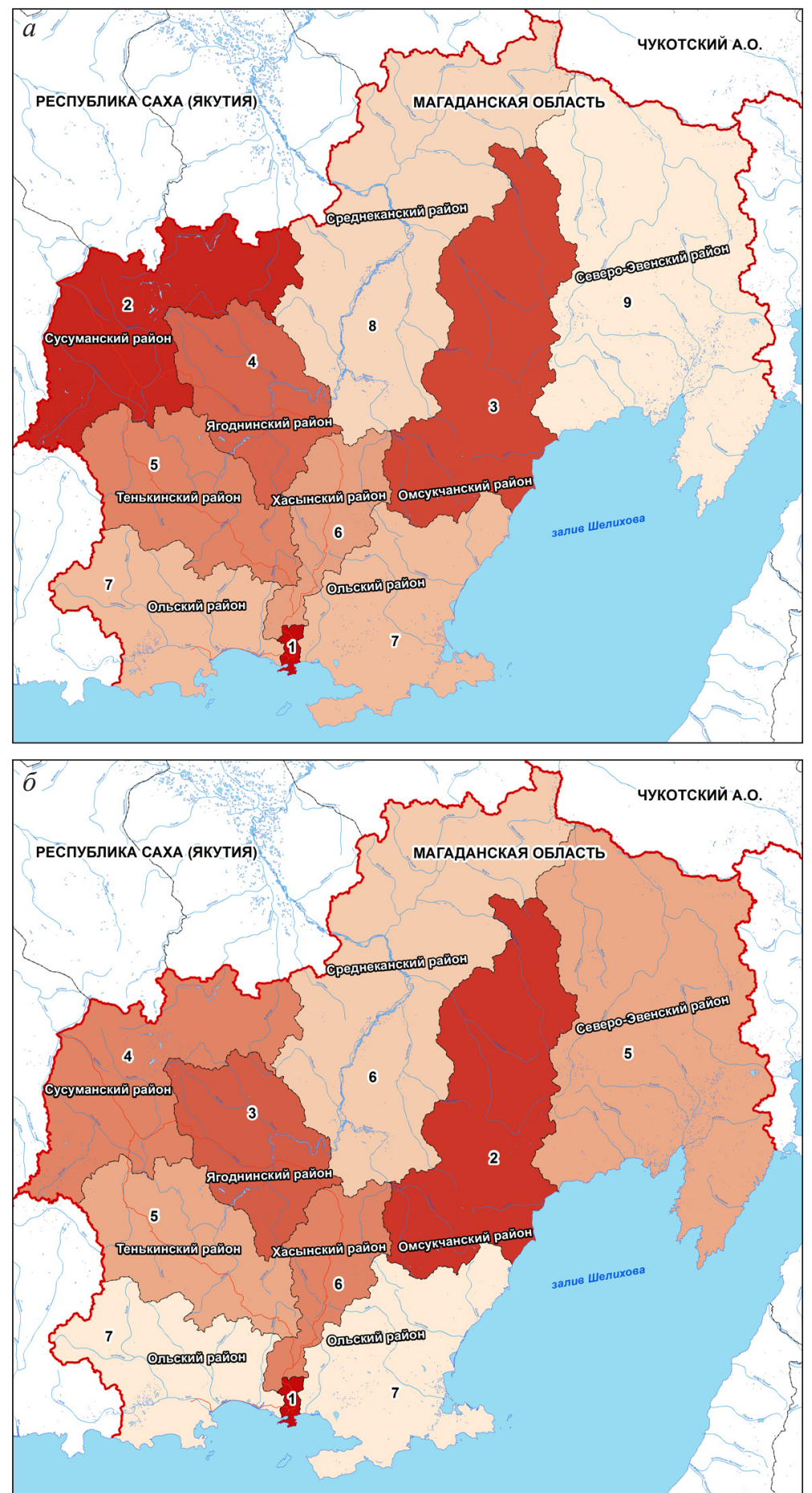

Puc. 4. Рейтинг социально-экономического положения районов Магаданской области: $a$ - в 2007 г., $\sigma$ - в 2018 г.

Fig. 4. Rating of socio-economic situations in Magadan Oblast districts: $a-2007, \sigma-2018$ лее заселенных территорий. В 2018 г. в лидерах г. Магадан, Ягоднинский и Хасынский районы. Худшая ситуация по показателям социальной сферы за оцениваемый период сохраняется в Северо-Эвенском (самом малозаселенном и транспортно-изолированном) и Ольском городских округах (второй по численности после г. Магадана, но с низким уровнем развития производственной сферы).

Обобщенная рейтинговая оценка (производственного, финансового и развития социальной сферы) рассчитывается как среднее арифметическое рангов всех 3 групп. Результаты обобщенной рейтинговой оценки социально-экономического положения районов Магаданской области в 2007 г. свидетельствуют о лидирующих позициях г. Магадана, Сусуманского, Омсукчанского и Ягоднинского районов и о низком уровне социально-экономического развития Северо-Эвенского, Ольского и Среднеканского районов (рис. $4, a$ ). В 2018 г. районы-лидеры остались прежними с небольшими изменениями в рангах. Внимания руководства районного и областного уровней к созданию условий для поддержки и активного развития территорий требуют районы-аутсайдеры: Ольский и Среднеканский (рис. 4, б).

Рейтинг территорий по динамике развития. Для оценки динамики использовали темпы роста (снижения) показателей социальноэкономического развития районов за 2018 г. по отношению к данным за 2007 г.: промышленного производства, задолженности по выплате заработной платы работникам, уровня регистрируемой безработицы, среднемесячной номинальной начисленной заработной платы, объема жилищного фонда, инвестиции в основной капитал (табл. 7). По темпам развития оцениваемых в динамике показателей картина итогового рейтинга выглядит немного иначе. В 2007 г. относительно 2006 г. 1-е место занимал г. Магадан, 2-е место - Сусуманский район, 3-е место у СевероЭвенского и Среднеканского районов (см. табл. 7). С 2007 по 2018 г. наиболее динамичное развитие продемонстрировали Омсукчанский, Среднеканский и Хасынский районы. 


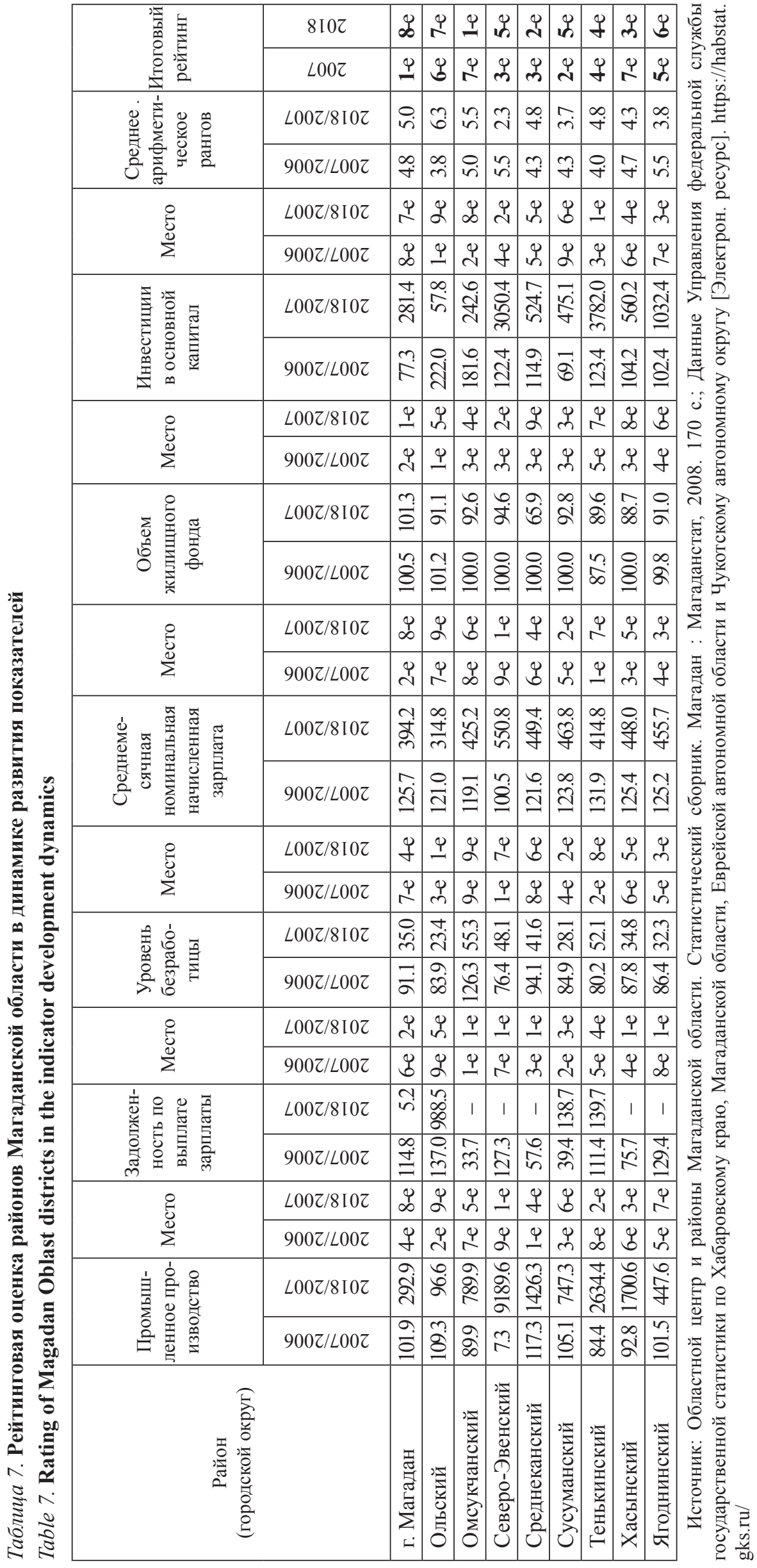




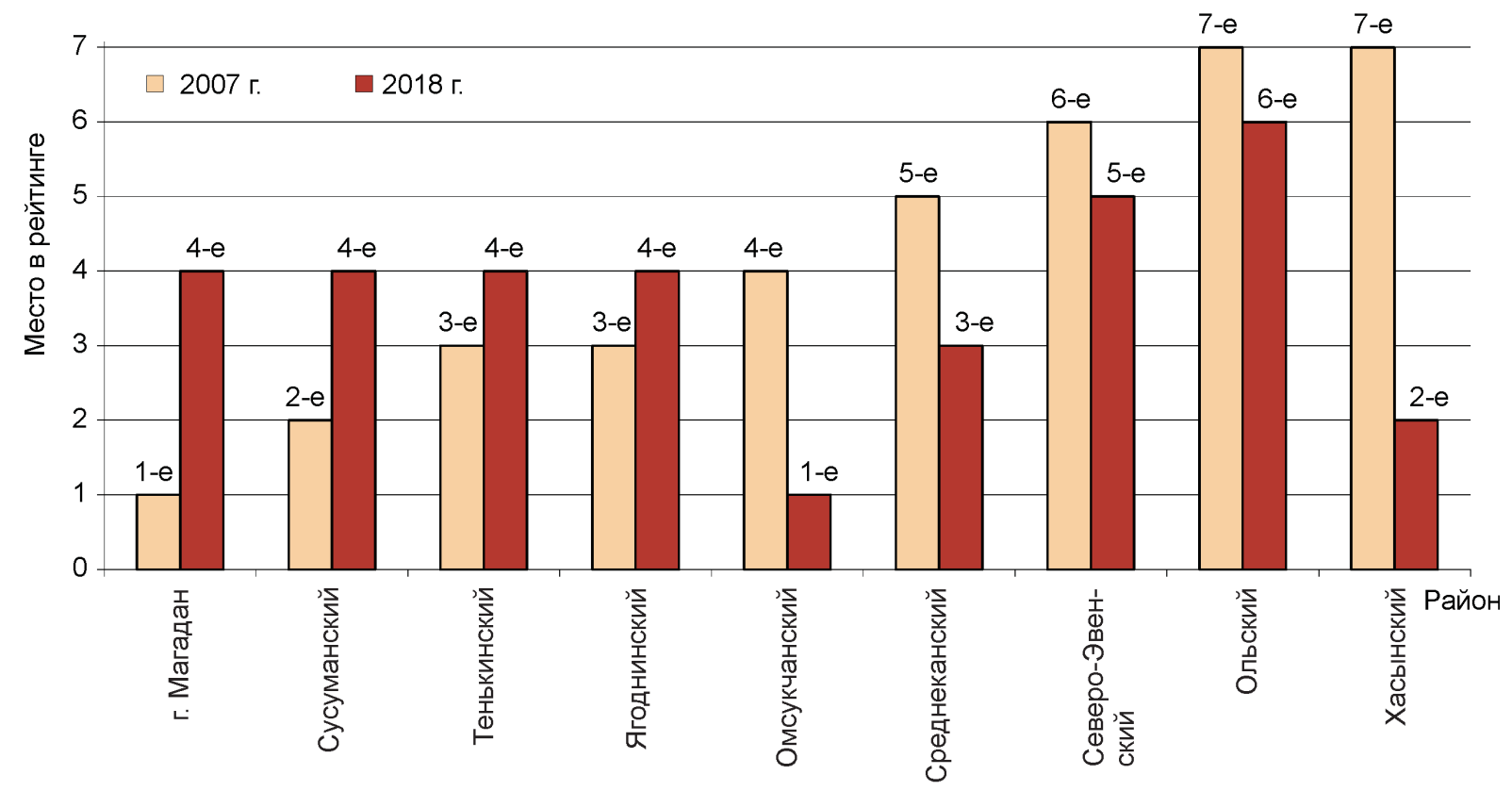

Puc. 5. Интегральная рейтинговая оценка социально-экономического положения районов Магаданской области

Fig. 5. Integral rating of socio-economic situations in Magadan Oblast districts

Смена динамики в развитии районов области обусловлена в большей степени реализацией крупных проектов в минерально-сырьевом комплексе, а также стратегических национальных проектов в рамках различных государственных программ по развитию территории (строительство дорог, ЛЭП и т. п.).

Пульсация темпов социально-экономического развития - нормальное для северных и арктических регионов явление, и оптимальная социальноэкономическая стратегия должна базироваться не на противостоянии тенденциям, а на адаптации к ним (Замятина, Пилясов, 2017).

Интегральный рейтинг. На основе результатов рейтинга социально-экономического положения районов в базовом году и динамики развития оценен общий интегральный рейтинг (рис. 5).

По результатам интегральной оценки в 2007 г. лидерство в рейтинге принадлежало г. Магадану, Сусуманскому, Тенькинскому и Ягоднинскому районам. А в 2018 г., с учетом динамики с 2007 г., рейтинг изменился. Лидером стал Омсукчанский район, перешли в лидирующую группу Хасынский и Среднеканский районы (см. рис. 5). Лидеры 2007 г. с одинаковым результатом занимают 4-е место. В группе аутсайдеров продолжают оставаться Ольский и Северо-Эвенский районы.

Степень объективности результатов могла бы быть выше при использовании более широкого спектра статистических показателей. Но в силу того, что по ряду производственных показателей в отдельных муниципальных образованиях данные не публикуются в целях обеспечения конфиденциальности первичных статистических дан- ных, полученных от организаций в соответствии с Федеральным законом от 29.11.2007 г. № 282Ф3 «Об официальном статистическом учете и системе государственной статистики в Российской Федерации», не все показатели удалось учесть в оценке рейтинга. Так, по ряду муниципальных образований не публикуются следующие показатели: разница между просроченной кредиторской и дебиторской задолженностью, сальдированный финансовый результат организаций, оборот розничной торговли и др.

\section{ЗАКЛЮЧЕНИЕ}

Одна из задач регионального развития обоснование перспектив развития муниципальных образований, эффективное решение которой возможно посредством ведения мониторинга их экономического и социального развития.

Рейтинг социально-экономического положения муниципальных образований Магаданской области по итогам 2007 и 2018 г. определил позиции каждого района в развитии региона, а также позволил выявить сильные и слабые звенья и уровень динамики развития.

Кардинальные изменения в рейтинге по группе показателей производственной сферы в 2018 г. продемонстрировали Омсукчанский (с 5-го на 3-е место) и Северо-Эвенский (с 7-го на 4-е место) районы.

По группе показателей финансовой сферы худшие места в рейтинге у Ольского, Среднеканского и Северо-Эвенского районов. Бюджеты всех муниципальных образований продолжают оставаться хронически дотационными. 
В социальной сфере самый низкий рейтинг у Ольского, Тенькинского и Северо-Эвенского районов, обусловленный различными причинами: низким уровнем промышленного производства, преимущественно вахтовой работой, инфраструктурной неразвитостью соответственно.

За оцениваемый период 2007-2018 гг. наиболее динамичное развитие в социально-экономическом развитии продемонстрировали Омсукчанский, Среднеканский и Хасынский районы, в меньшей степени - Ольский район и г. Магадан.

По итогам интегральной оценки, учитывающей места муниципальных образований на конкретную дату (2018 г.) и в динамике (за 20072018 гг.), самый низкий рейтинг у Ольского и Северо-Эвенского районов, причем аналогичный результат наблюдался и в 2007 г.

Проведенный анализ показателей рейтинга социально-экономического развития районов Магаданской области позволяет определить направления модернизации их экономики. Для сохранения стабильной социально-экономической обстановки в передовых районах Магаданской области и подтягивания отсталых к уровню лидеров необходимо оценить возможности имеющихся инвестиционных проектов.

Для выравнивания социально-экономического положения районов и развития области целесообразно начать их реализацию в первую очередь в районах с низкими рейтинговыми показателями.

В настоящее время это Ольский, Среднеканский и Хасынский районы, занимающие самые низкие места в рейтинге по производственным показателям как в 2007, так и в 2018 г.

Дальнейшие перспективы муниципальных образований и области тесно связаны с современной экономической специализацией. Но, с учетом имеющихся на территории Магаданской области проектов в различных отраслях, некоторые районы получат возможность специализации в относительно нетрадиционных (или второстепенных в настоящее время) для них видах экономической деятельности (Шарыпова и др., 2010).

Так, г. Магадан и Ольский район имеют существенный потенциал роста по специализации «строительство» и «транспорт» в результате реализации проектов по добыче углеводородов на участках Примагаданского шельфа (лицензионные участки «Магадан-1, -2, -3, -4»). Перспективы Ольского района связаны также с реализацией крупного энергетического проекта - промышленным освоением Ланковского и Мелководнинского месторождений бурого угля с возможностью его комплексной переработки (Гальцева и др., 2015).
Северо-Эвенский и Среднеканский районы могут начать специализироваться в добывающей и обрабатывающей промышленности в случае реализации проектов по добыче соответственно железорудного сырья и меди, с одновременным строительством металлургических комбинатов по переработке.

Несмотря на то что по многим показателям Магаданская область занимает лидирующие позиции среди субъектов РФ, региону не хватает собственных ресурсов на преодоление социальных проблем, ставших отчасти следствием экстенсивного типа освоения территории еще в условиях плановой экономики.

Процесс сжатия обитаемого пространства в регионе продолжается естественным путем с очень большими издержками как для населения, так и для государства. Для модернизации социально-экономического развития Магаданской области необходима новая пространственная модель оптимального расселения и концентрации производительных сил, возможно, с корректировкой границ муниципальных образований на уровне субъектов и укрупнением муниципальных районов в целях увеличения их внутреннего потенциала и совершенствования территориального управления.

\section{ЛИТЕРАТУРА}

Гальцева Н. В., Фавстрицкая О. С., Шарыпова О. А. Перспективы производства экспортоориентированной продукции в Магаданской области // Вестник СВНЦ ДВО РАН. 2015. № 4. С. 101-111.

Гальиева Н. В., Фастриикая О. С., Шарыпова О. А. Уровень жизни населения северных и арктических территорий Дальнего Востока России // Региональная экономика: теория и практика. 2017. Т. 15. Вып. 1. C. $85-100$.

Замятина Н. Ю., Пилясов А. Н. Региональный консалтинг: приглашение у творчеству. Опыт разработки документов стратегического планирования регионального и муниципального уровня. СПб. : Маматов, 2017. $196 \mathrm{c}$.

Кузин В. Ю. Процесс метрополизации современной России в контексте поляризации // Псковский регионологический журнал. 2019. № 1 (37). С. 33-45.

Ушаков E. А. Социально-экономическое развитие муниципальных районов Крайнего Севера (на примере Магаданской области и северных районов Хабаровского края) // Муниципальные образования современных регионов : проблемы исследования, развития и управления в условиях геоэкономической и политической нестабильности : материалы Первой междунар. науч.-практ. конф. 1415 апр. 2016 г., Воронежский гос. университет / под общ. ред. проф. Н. В. Яковенко. Воронеж : Издат.полиграф. центр «Научная книга», 2016. С. 76-79.

Шарыпова О. А. Определение рейтинга социальноэкономического положения муниципальных районов Магаданской области // European Social Science Jour- 
nal (Европейский журнал социальных наук). 2011. № 12. C. 351-362.

Шарыпова О. А., Голубенко И. С., Гальцеев И. Н. Оценка кластерного потенциала базовых видов экономической деятельности в районах Магаданской области // VI Диковские чтения : Материалы науч.практ. конф., посвящ. 85-летию со дня рожд. Н. Н.
Дикова и 50-летию образования СВКНИИ ДВО РАН. Магадан : СВКНИИ ДВО РАН, 2010. С. 281283.

Шарыпова О. А., Голубенко И. С., Гальцев И. Н. Рейтинг социально-экономического положения районов Магаданской области // Экономика и управление. 2009. № 13 (спецвыпуск). С. 52-59.

Поступила в редакиию 14.10.2019 2.

\title{
RATING OF SOCIO-ECONOMIC SITUATIONS IN MAGADAN OBLAST MUNICIPALITIES (2007-2018)
}

\begin{abstract}
Sharypova O. A., Galtseva N. V., Favstritskaya O. S.,
North-East Interdisciplinary Scientific Research Institute n. a. N. A. Shilo, FEB RAS, Magadan

A comparative analysis of the social and economic situation in Magadan Oblast in 2007 and 2018 has been carried out by the basic indicators. Magadan Oblast municipalities (urban districts) have been rated on the basis of three indicator groups: production, financial, and social. Leaders and outsiders have been identified. Qualitative analysis of the results of the generalized results of the district socio-economic rating in 2007 and 2018 have been qualitatively analized.
\end{abstract}

Keywords: municipal entities, districts, Magadan Oblast, socio-economic situation, rating .

\section{REFERENCES}

Galtseva, N. V.; Favstritskaya, O. S.; Sharypova, O. A., 2015, Prospects of Export-Oriented Production in Magadan Oblast, Vestnik NESC FEB RAS, 4, 101-111 [In Russian].

Galtseva, N. V.; Favstritskaya, O. S.; Sharypova, O. A., 2017 , Standard of Living of the Population in the Northern and Arctic Areas of the Russian Far East, Regional Economics: Theory and Practice, 15, 1, 85-100 [In Russian].

Kuzin, V. Yu., 2019, Metropolization Process of Contemporary Russia in the Context of Polarization, Pskov Regional Studies Magazine, 1 (37), 33-45 [In Russian].

Sharypova, O. A., 2011, Analysis of the Rating of the Social and Economic Position of the Municipal Districts of Magadan Oblast, European Social Science Journal , 12, 351-362 [In Russian].

Sharypova, O. A.; Golubenko I. S., Galtsev I. N., 2009, Rating of the Social and Economic Position of the Districts of Magadan Oblast, Economics and Management, No. 13 (Special Issue), 52-59 [In Russian].
Sharypova, O. A.; Golubenko, I. S.; Galtsev, I. N., 2010, Assessment of the Cluster Potential of Basic Economic Activities in the Districts of Magadan Oblast, The VI Dikov Readings: Proceedings of the Scientific Conference in Honor of the $85^{\text {th }}$ Anniversary of N. N. Dikov and the $50^{\text {th }}$ Anniversary of NEISRI FEB RAS, Magadan, NEISRI FEB RAS, 281-283 [In Russian].

Ushakov E. A., 2016, Socio-Economic Development of Municipal Districts of the Far North (on the Example of Magadan Oblast and Northern Districts of Khabarovsk Krai), Municipal Entities of Modern Regions: Problems of Research, Development, and Management in Conditions of Geo-Economic and Political Instability : Materials of the First International Science Conference, April 14-15, Ed. Prof. N. V. Yakovenko, Voronezh, Scientific Book, 76-79 [In Russian].

Zamyatina N. Yu., Pilyasov A. N., 2017, Regional Consulting: Invitation to Creativity, Experience in the Development of Strategic Planning Documents at the Regional and Municipal Levels, St. Petersburg : Mamatov [In Russian]. 